\title{
Are Adolescent Boys with Klinefelter Syndrome Androgen Deficient? A Longitudinal Study of Finnish 47,XXY Boys
}

\author{
ANNE M. WIKSTRÖM, LEO DUNKEL, SANNA WICKMAN, ENSIO NORJAVAARA, CARINA ANKARBERG-LINDGREN, \\ AND TANELI RAIVIO
}

\begin{abstract}
Hospital for Children and Adolescents [A.M.W., L.D., S.W., T.R.], Helsinki University Central Hospital, University of Helsinki, 00029 Helsinki, Finland; Department of Pediatrics [L.D.], Kuopio University Hospital, University of Kuopio, 70211 Kuopio, Finland; Göteborg Pediatric Growth Research Center [E.N., C.A.-L.], Institute for Health of Women and Children, The Sahlgrenska Academy at Göteborg
\end{abstract} University, 41685 Göteborg, Sweden

\begin{abstract}
Testosterone (T)-substitution therapy is widely used in adult patients with Klinefelter syndrome (KS) to prevent symptoms and sequels of androgen deficiency, but it is currently unknown if adolescent boys with KS benefit from early T therapy. To evaluate the optimal age to start $\mathrm{T}$ substitution, we searched for signs of androgen deficiency in pubertal boys with KS. 14 nonmosaic $47, \mathrm{XXY}$ boys, aged 10-13.9 y, were followed up for 4-37 mo with staging of puberty and frequent reproductive hormone measurements. Furthermore, indices reflecting androgen action (serum SHBG, leptin, and prostate-specific antigen (PSA) levels) were studied. Both onset and progression of puberty according to Tanner stages were normal in boys with KS. Consistently, serum T concentrations increased as expected and remained normal throughout follow-up. Changes in the indices of androgen action (decreases in serum SHBG and leptin, and increase in serum PSA concentrations) occurred normally, except that average leptin levels were higher in the boys with KS (KS boys $11.8 \pm 7.0 \mu \mathrm{g} / \mathrm{L}$; controls $7.6 \pm 4.7 \mu \mathrm{g} / \mathrm{L} ; p=$ 0.033 ). Despite normal T concentrations, the KS boys displayed from the age of 13 y elevated serum FSH and LH levels, and exaggerated gonadotropin responses to gonadotropin-releasing hormone. These data do not demonstrate an unequivocal androgen deficiency in adolescent boys with KS that would necessitate androgen supplementation therapy during early puberty. (Pediatr Res 59: 854-859, 2006)
\end{abstract}

$\mathrm{K}^{\mathrm{s}}$ $\mathrm{S}$ with its estimated prevalence of 152 per 100,000 males is a common form of male hypogonadism (1). Only subtle physical signs, such as an increase in height velocity, long-leggedness, slightly lower than normal testicular volume and a tendency to central obesity may be evident before puberty (2,3). Prepubertal boys with KS often have delayed speech development and learning disabilities, difficulties in relationships with peers and siblings, and have quiet and unassured manner (3). All these symptoms have been related to androgen deficiency.

Received November 15, 2005; accepted January 16, 2006.

Correspondence: Anne Wikström, M.D., HUCH, Hospital for Children and Adolescents, PO Box 281, 00029 Helsinki, Finland; e-mail: anne.wikstrom@fimnet.fi

Supported by grants from the Medical Society of Finland (Finska Läkaresällskapet) (AW), the Finnish Medical Foundation (AW, TR), the Finnish Cultural Foundation (TR), the Foundation for Pediatric Research (TR), and the Hospital District of Helsinki and Uusimaa.

DOI: 10.1203/01.pdr.0000219386.31398.c3
Testes of adult KS males are characterized by hyalinization and fibrosis of the seminiferous tubules, and hyperplasia of the Leydig cells (4). The mechanisms leading to degeneration of the seminiferous tubules are unknown, but this process seems to accelerate at the onset of puberty (5). Prepubertal boys with the 47,XXY karyotype have only slightly reduced testicular volume $(6,7)$, and the hypergonadotropism typical of adult KS patients cannot be detected before midpuberty $(5,8,9)$. Boys with KS do not typically display delayed onset of puberty and their serum testosterone ( $\mathrm{T}$ ) levels usually remain within the low normal range throughout puberty $(5,8,9)$. Serum LH levels usually further increase from midpuberty onwards, probably reflecting a compensatory feedback mechanism to maintain sufficient Leydig cell function $(5,8,9)$. After pubertal maturation, these compensatory efforts may fail to maintain sufficient circulating $\mathrm{T}$ levels, and subsequently $\mathrm{T}$ substitution therapy is widely used in adult KS patients to avoid symptoms and sequels of androgen deficiency $(2,10)$.

It has been proposed that adolescent boys with KS may benefit from early $\mathrm{T}$ therapy (11-15). Reports, however, are lacking that verify hypoandrogenism in $47, \mathrm{XXY}$ boys during puberty or examine their androgen status before the start of treatment (11-15). Consequently, the optimal age for initiating androgen therapy remains unclear. Our aim was therefore to use clinical and laboratory data from a longitudinal observation period of 14 adolescent nonmosaic 47,XXY boys to determine whether they displayed signs of androgen deficiency during early puberty.

\section{SUBJECTS AND METHODS}

Subjects. Fourteen nonmosaic 47,XXY boys (KS group) were followed up prospectively for 4-25 mo (median, 18). In addition, data from routine clinical visits prior and after the systematic surveillance period were collected from patient records. None of the subjects was or had previously been on androgen therapy. At the start of the systematic prospective follow-up, their

Abbreviations: BA, bone age; CDP, constitutional delay of puberty; CV, coefficient of variation; E2, 17 $\beta$-estradiol; GnRH, gonadotropin-releasing hormone; KS, Klinefelter syndrome; PSA, prostate-specific antigen; SHBG, sex hormone-binding globulin $\mathrm{T}$, testosterone 
median age was $11.5 \mathrm{y}$ (range, 10.0-13.9), and their median BA, according to the method of Greulich and Pyle (16), also 11.5 y (range, 7.5-14.5). Some of the clinical and hormonal data have already been published (5).

The boys visited the Hospital for Children and Adolescents in Helsinki every fourth to sixth month. At each visit, puberty was staged according to Tanner (17), and sera were taken for hormone measurements. The venous blood samples were drawn between 0730 and $1530 \mathrm{~h}$. Body mass indices (BMI) were calculated as weight $(\mathrm{kg})$ divided by the square of height $\left(\mathrm{m}^{2}\right)$. Width and length of the testes were measured with a ruler to the nearest millimeter; testicular volume was calculated by the formula $0.52 \times$ length $\times$ width $^{2}$ (18). BA was assessed annually, and GnRH stimulation test performed: serum FSH was measured at 0 (before), 30, 60, and $90 \mathrm{~min}$., and serum LH at 0 (before), 20, 30, and 60 min following an intravenous injection of GnRH (Relefact, Hoechst Marion Roussel, Frankfurt, Germany) $3.5 \mu \mathrm{g} / \mathrm{kg}$; maximum $100 \mu \mathrm{g}$. The parents of each boy gave their informed consent for participation in this study approved by the ethics committee for pediatrics, adolescent medicine and psychiatry of the Hospital District of Helsinki and Uusimaa.

For comparison of serum $\mathrm{T}$ and $\mathrm{E} 2$ levels in $\mathrm{KS}$ boys to values in healthy adolescent boys, we used recently published reference values from 55 healthy Swedish boys $(19,20)$. These boys, aged 5.0-18.6 y, had undergone serial sampling for 24-h serum $\mathrm{T}$ and $\mathrm{E} 2$ profiles once or repeatedly during pubertal development; their venous blood samples were drawn six times during $24 \mathrm{~h}$.

Furthermore, we investigated in KS boys longitudinal changes in serum concentrations of SHBG, PSA, leptin, FSH, LH, and inhibin B levels and compared these to values in 25 healthy, untreated Finnish boys with CDP previously followed up in our unit $(21,22)$. For assessment of laboratory values for the $\mathrm{CDP}$ group, when compared with the KS group, BA rather than chronological age (CA) was used, since BA in the CDP group were delayed [difference from CA (mean $\pm \mathrm{SD}$ ) $-2.40 \pm 0.67$ y during follow-up]. For assessment of laboratory values in KS boys CA were used, because differences between BA and CA in these boys during the study period were small (mean difference $-0.36 \pm 1.11 \mathrm{y}$ ).

Biochemical measurements. Venous blood samples were allowed to clot; serum was separated by centrifugation and stored at $-20 \mathrm{C}$ or $-70 \mathrm{C}$.

To allow direct comparison between serum $\mathrm{T}$ and $\mathrm{E} 2$ concentrations in the KS boys and the healthy Swedish boys, serum T and E2 levels in both groups were measured in the same laboratory. For serum $\mathrm{T}$, an ultrasensitive (sensitivity, $0.03 \mathrm{nmol} / \mathrm{L}$ ) modified RIA was used (Spectria testosterone, Orion Diagnostica, Espoo, Finland) (23). The intra-assay CV was $11 \%$ at $0.2 \mathrm{nmol} / \mathrm{L}$, and $<7 \%$ at concentrations $>0.9 \mathrm{nmol} / \mathrm{L}$; the corresponding interassay CV were $15 \%$ and $<10 \%$, respectively. Serum E2 concentrations were measured with a modified RIA (Spectria estradiol, Orion Diagnostica, Espoo, Finland) after diethyl ether extraction $(20,24)$. The assay detection limit was $4.5 \mathrm{pmol} / \mathrm{L}$, intra-assay $\mathrm{CV}$ was $13 \%$ at $19 \mathrm{pmol} / \mathrm{L}$, and interassay $\mathrm{CV} 12 \%$ at $22 \mathrm{pmol} / \mathrm{L}$.

Serum SHBG concentrations were measured by time-resolved fluoroimmunoassay (Perkin-Elmer Life Sciences, Turku, Finland) with inter- and intra-assay CVs both less than $5 \%$ according to the manufacturer. Serum leptin was quantitated with a commercially available RIA from Linco Research Inc., St. Charles, MO. The detection limit of this assay is $0.5 \mu \mathrm{g} / \mathrm{L}$. Interassay $\mathrm{CV}$ was $<7 \%$ (concentration range, $5-25 \mu \mathrm{g} / \mathrm{L}$ ).

Serum PSA was quantitated with a time-resolved immunofluorometric assay (Prostatus PSA EQM DELFIA, Wallac, Turku, Finland). The detection limit for PSA was $0.02 \mu \mathrm{g} / \mathrm{L}$. Interassay $\mathrm{CV}$ was $<4 \%$ at PSA concentrations 0.2 to $100 \mu \mathrm{g} / \mathrm{L}$.

Serum FSH and LH levels were measured by ultrasensitive immunofluorometric assays, as described (25). FSH and LH concentrations $0.1 \mathrm{IU} / \mathrm{L}$ were treated as $0.1 \mathrm{IU} / \mathrm{L}$. For FSH, interassay $\mathrm{CV}$ was $<3.3 \%$ and intra-assay $\mathrm{CV}<4.4 \%$; for $\mathrm{LH}<4.4 \%$ and $<4.1 \%$. Serum inhibin B levels were measured by a commercially available immunoenzymometric assay according to manufacturer's instructions (Serotec, Oxford, UK). The detection limit was $15.6 \mathrm{pg} / \mathrm{mL}$. The interassay CV was $<15 \%$ and the intra-assay $\mathrm{CV}<5 \%$.

Statistical analyses. Descriptive data are reported as median and range or as mean $\pm \mathrm{SD}$. Because the same subjects were investigated repeatedly, we used the method of summary measures (26). Arithmetic means were first calculated for each individual and subsequently these individual means served as raw data in the unpaired two-tailed $t$ test. A value of $p<0.05$ was considered statistically significant.

\section{RESULTS}

Clinical progression of puberty. In the 14 boys with KS, both onset and progression of puberty, as assessed by Tanner stages (17), fell within the normal range for healthy Finnish boys (27) (Fig. 1, $A$ and $B$, Table 1). At the end of the study period, only one, aged 12.5 , was at $\mathrm{P} 1$, but had entered puberty (stage G2). Although Tanner stages progressed normally during follow-up, there was an arrest in testicular growth, and testicular volumes of the $14 \mathrm{KS}$ subjects never exceeded $4.5 \mathrm{~mL}$ (Fig. $1 C$ and Table 1). Mean testicular volume of $2.0 \mathrm{~mL}$, accepted to indicate clinical onset of puberty, occurred at median age 12.6 y (range, $11.7-13.9 ; n=13$ ), and $3.0 \mathrm{~mL}$ at $13.1 \mathrm{y}(11.8-14.9, n=8)$ (Fig. $1 C$ and Table 1$)$.

During follow-up, gynecomastia occurred in $11 \mathrm{KS}$ boys, at G2 in two boys, at G3 in five, and at G4 in four. In five boys, it was reversible, and only one of these 11 boys had reached Tanner stage M3.

No significant delay in skeletal maturation during puberty occurred in the KS boys, as evidenced by a strong linear relationship between progression of BA and CA (Fig. 1D). Only during prepuberty did three boys show a significant delay in bone maturation of 2.1-2.5 y, but it caught up with advancing age. One boy displayed an advanced BA of 2.4 y before onset of puberty. Otherwise, BA of the KS boys were within the mean $\pm 2 \mathrm{SD}$ for healthy Finnish boys during puberty (27) (Fig. 1D).

Serum T levels during puberty. Longitudinal changes in circulating $\mathrm{T}$ levels in the KS boys and in 41 healthy boys of similar age $(19,20)$ are shown in Figure $2 A$. Diurnal rhythm of serum $\mathrm{T}$ was taken into consideration by grouping the samples according to time of day; serum $\mathrm{T}$ levels measured before (0747-1000 h) or after $1000 \mathrm{~h}(1001-1510 \mathrm{~h})$ were compared
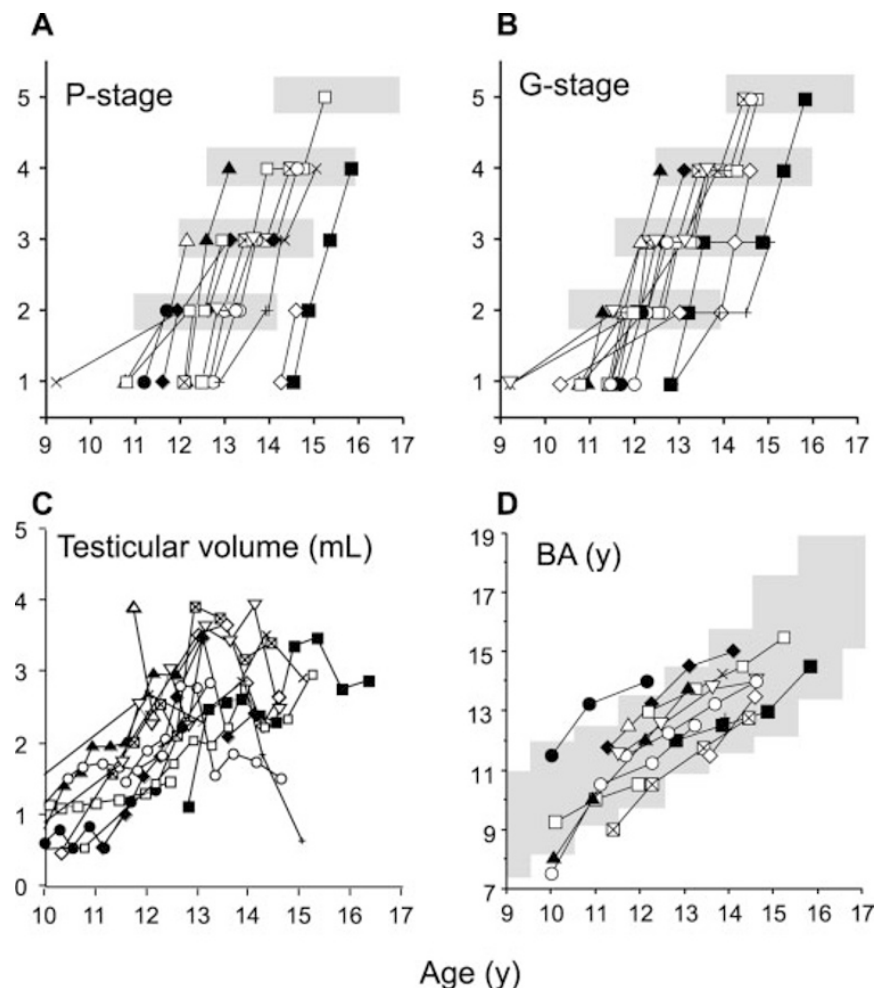

Figure 1. Pubertal development in 14 boys with KS. $(A, B)$ Puberty staged according to Tanner. Gray rectangles $=$ mean age \pm 2 SD for healthy Finnish boys (27). (C) Longitudinal changes in mean testicular volumes. (D) Progression of BA against chronological age. Gray area $=$ mean BA \pm 2 SD for healthy Finnish boys. 
Table 1. Follow-up of 14 adolescent boys with $K S$

\begin{tabular}{|c|c|c|c|c|c|c|}
\hline Age (y) & $10-11$ & $11-12$ & $12-13$ & $13-14$ & $14-15$ & $15-16$ \\
\hline Tanner P-stage* & $1(9)$ & $1,1-2(9)$ & $2,1-3(13)$ & $2.5,1-4(11)$ & $3,1-4(9)$ & $4,3-5(4)$ \\
\hline Tanner G-stage* & $1(9)$ & $1,1-2(9)$ & $2,1-4(13)$ & $3.5,2-4(11)$ & $4,2-5(9)$ & $4,3-5(4)$ \\
\hline Mean testicular volume $(\mathrm{mL})$ & $1.1 \pm 0.5(5)$ & $1.8 \pm 0.9(9)$ & $2.1 \pm 0.5(12)$ & $2.9 \pm 0.5(11)$ & $2.6 \pm 0.7(9)$ & $2.4 \pm 1.2(4)$ \\
\hline Bone age (y) & $9.5 \pm 2.1(4)$ & $11.0 \pm 1.2(7)$ & $12.3 \pm 1.1(9)$ & $13.1 \pm 1.0(11)$ & $13.8 \pm 0.8(7)$ & $15.0 \pm 0.7(2)$ \\
\hline BMI $\left(\mathrm{kg} / \mathrm{m}^{2}\right)$ & $17.7 \pm 2.2(8)$ & $19.3 \pm 2.7(10)$ & $19.3 \pm 2.9(13)$ & $19.7 \pm 2.4(11)$ & $19.7 \pm 3.1(9)$ & $18.9 \pm 2.0(4)$ \\
\hline Testosterone (nmol/L) & $0.53 \pm 0.43(4)$ & $0.78 \pm 0.37(9)$ & $2.81 \pm 2.68(7)$ & $5.65 \pm 4.50(7)$ & $7.60 \pm 3.62(6)$ & \\
\hline Estradiol (pmol/L) & $10.9 \pm 3.1(3)$ & $11.6 \pm 5.5(5)$ & $16.4 \pm 4.8(6)$ & $26.4 \pm 16.5(4)$ & $32.5 \pm 10.7(4)$ & \\
\hline SHBG nmol/L) & $94 \pm 46(4)$ & $80 \pm 37(8)$ & $77 \pm 44(10)$ & $52 \pm 19(11)$ & $46 \pm 13(7)$ & $31 \pm 8(2)$ \\
\hline $\mathrm{PSA}(\mu \mathrm{g} / \mathrm{L})$ & $0.024 \pm 0.022$ & $0.038 \pm 0.042(9)$ & $0.077 \pm 0.058(7)$ & $0.216 \pm 0.184(7)$ & $0.369 \pm 0.254(5)$ & \\
\hline Leptin $(\mu \mathrm{g} / \mathrm{L})$ & $14.1 \pm 7.3(4)$ & $14.7 \pm 7.9(9)$ & $14.7 \pm 7.3(11)$ & $9.8 \pm 6.0(11)$ & $8.9 \pm 6.8(9)$ & $13.8 \pm 8.0(2)$ \\
\hline Basal LH (IU/L) & $0.2 \pm 0.1(6)$ & $0.5 \pm 0.3(10)$ & $2.3 \pm 2.9(13)$ & $6.4 \pm 3.5(11)$ & $11.4 \pm 6.1(9)$ & $15.8 \pm 5.8(4)$ \\
\hline $\begin{array}{l}\Delta \mathrm{LH}(\mathrm{IU} / \mathrm{L}) \\
(95 \% \mathrm{CI} \text { for boys with CDP) } \\
\text { after GnRH stimulation }\end{array}$ & $3.6 \pm 3.3(4)$ & $\begin{array}{c}8.7 \pm 7.9(7) \\
(5.8-14.2)\end{array}$ & $\begin{array}{c}10.4 \pm 6.6(6) \\
(12.8-23.2)\end{array}$ & $\begin{array}{c}36.4 \pm 24.4(6) \\
(14.4-20.4)\end{array}$ & $\begin{array}{c}25.6 \pm 16.2(3) \\
\quad(16.2-25.4)\end{array}$ & \\
\hline Basal FSH (IU/L) & $1.2 \pm 0.6(6)$ & $2.6 \pm 2.6(10)$ & $5.8 \pm 6.1(13)$ & $19.8 \pm 12.4(11)$ & $30.2 \pm 16.8(9)$ & $32.8 \pm 16.3(4)$ \\
\hline $\begin{array}{l}\Delta \mathrm{FSH}(\mathrm{IU} / \mathrm{L}) \\
\text { (95\% CI for boys with CDP) } \\
\text { after GnRH stimulation }\end{array}$ & $2.3 \pm 1.0(4)$ & $\begin{array}{c}3.5 \pm 3.5(7) \\
(0.5-2.9)\end{array}$ & $\begin{array}{c}2.1 \pm 1.5(6) \\
(1.5-3.9)\end{array}$ & $\begin{array}{c}13.9 \pm 11.7(6) \\
(1.7-3.3)\end{array}$ & $\begin{array}{l}9.2 \pm 7.5(3) \\
\quad(2.7-5.1)\end{array}$ & \\
\hline Inhibin B (pg/mL) & $90 \pm 25(4)$ & $93 \pm 64(9)$ & $96 \pm 59(12)$ & $48 \pm 52(11)$ & $41 \pm 60(8)$ & $23(1)$ \\
\hline
\end{tabular}

Means \pm SD (number of patients) and *median, range (n) are displayed. To reduce frequency bias, means, or medians were calculated for each subject to get one value to each age interval.

separately to those in the healthy controls measured at $0600 \mathrm{~h}$ or $1400 \mathrm{~h}$. KS boys did not have lower serum T levels than did controls in either group ( $p=\mathrm{NS}$ ). Despite their normal serum $\mathrm{T}$ levels, some of the older KS boys displayed hypergonadotropism, as evidenced by elevated ( $>6$ IU/L) serum LH levels (Fig. 2A).

Longitudinal changes in Serum E2 and E2/T ratios during puberty. Especially before age of 12, the KS boys had
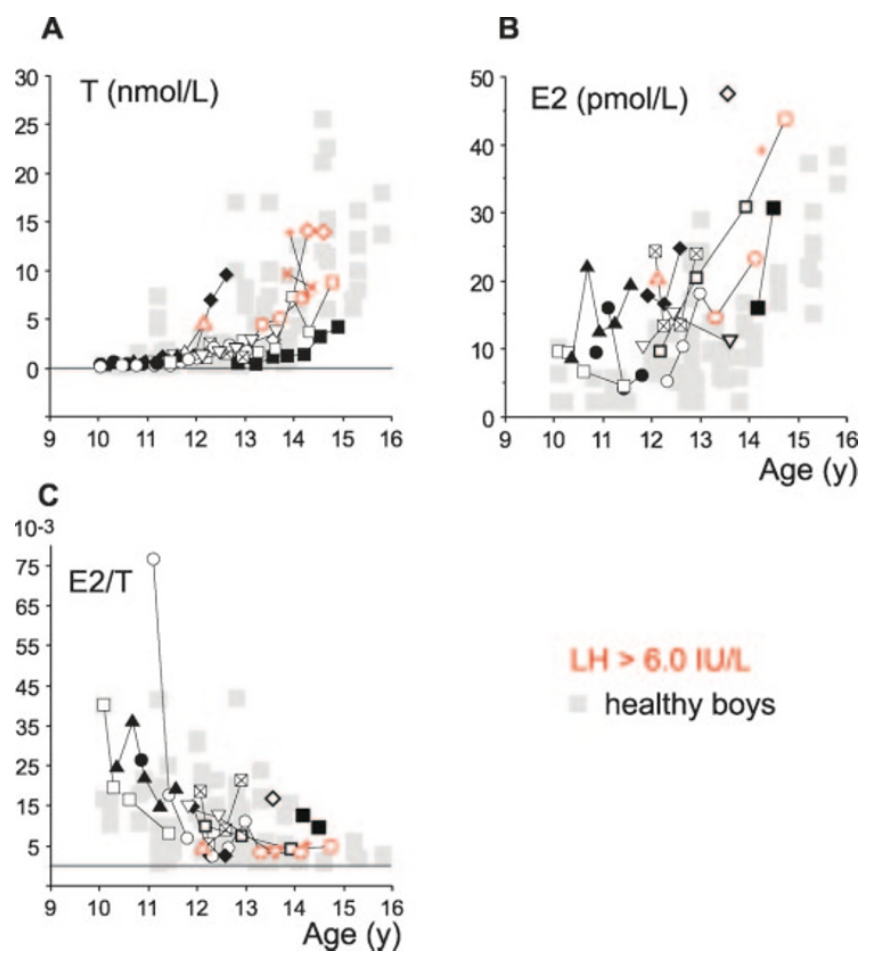

Figure 2. Longitudinal changes during puberty in 14 nonmosaic boys with KS: $(A)$ serum testosterone (T) in KS subjects; $(B)$ serum E2 in KS subjects; (C) E2-to-T ratios in KS subjects including those with and without serum $\mathrm{LH}$ $>6$ IU/L. Levels in healthy Swedish boys $(19,20)$ were measured at $0600 \mathrm{~h}$, $1000 \mathrm{~h}$, and $1400 \mathrm{~h}$. higher serum E2 levels than did healthy controls $(19,20)$. We also grouped the E2 samples according to time of day; the differences in serum E2 levels were significant in both groups (before $1000 \mathrm{~h}$ : KS boys $19.0 \pm 12.2 \mathrm{pmol} / \mathrm{L}, n=8$; controls $8.8 \pm 6.4 \mathrm{pmol} / \mathrm{L}, n=28, p=0.003$. After $1000 \mathrm{~h}$ : KS boys $18.0 \pm 9.2 \mathrm{pmol} / \mathrm{L}, n=12$; controls $7.3 \pm 5.4 \mathrm{pmol} / \mathrm{L}, n=$ $28, p<0.0001$, Fig. 2B). Differences in E2/T ratios (Fig. 2C) between the groups were not significant during prepuberty or puberty, but a tendency for higher E2/T ratios was noted in the KS boys (before $1000 \mathrm{~h}$ : KS boys $15.9 \pm 13.3, n=8$; controls $7.9 \pm 8.8, n=28, p=0.05$. After $1000 \mathrm{~h}$ : KS boys $13.3 \pm 9.1, n=12$; controls $14.0 \pm 9.4, n=28, p=\mathrm{NS}]$. During follow-up, no tendency appeared for higher E2 levels or higher E2/T ratios among the KS boys with gynecomastia than among those without (data not shown).

Longitudinal changes in SHBG, PSA, and leptin during puberty. During puberty, serum SHBG levels in KS boys decreased normally, with levels remaining in the normal range $(p=$ NS) (Fig. 3A). Figure $3 B$ shows longitudinal changes in serum PSA levels in KS boys; compared with 25 healthy boys with CDP $(21,22)$, both timing and magnitude of rise in serum PSA in the KS boys were normal $(p=\mathrm{NS})$.

Figure $3 C$ shows longitudinal changes in serum leptin levels in the 14 boys with KS. Levels decreased during puberty but were on average higher in the KS group than in healthy CDP controls (KS boys $11.8 \pm 7.0 \mu \mathrm{g} / \mathrm{L}$; controls $7.6 \pm 4.7 \mu \mathrm{g} / \mathrm{L}, p=0.033$; Fig. $3 C$ ). However, mean BMI between these groups did not differ (KS boys $19.0 \pm 2.4$ $\mathrm{kg} / \mathrm{m}^{2}$; controls $18.7 \pm 2.5 \mathrm{~kg} / \mathrm{m}^{2}, p=\mathrm{NS}$, Fig. $3 D$ ). A slight increase in BMI during puberty appeared in both groups (Fig. 3D). When serum leptin levels were adjusted for BMI, leptin/BMI ratios declined with advancing puberty in both groups, but the KS boys still had higher ratios than did controls (KS boys $0.57 \pm 0.30$; controls $0.39 \pm 0.22, p=$ 0.041, Fig. 3E). 
A

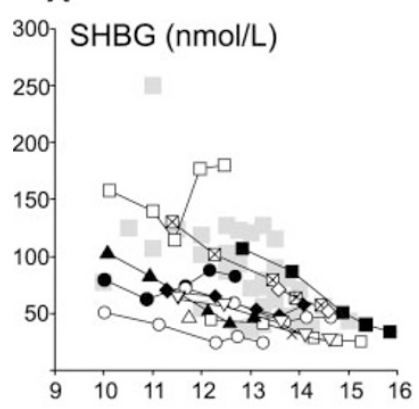

C

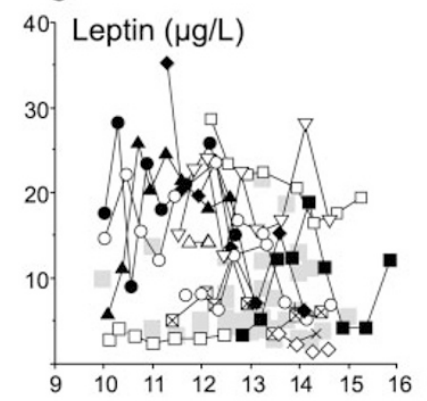

E

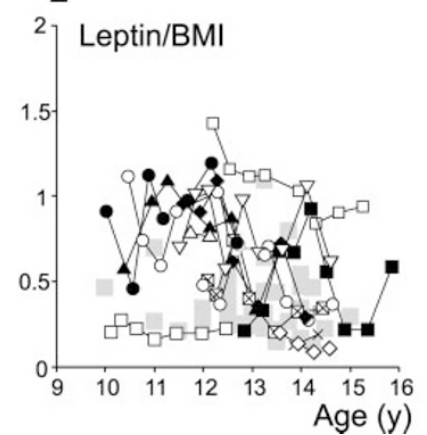

B
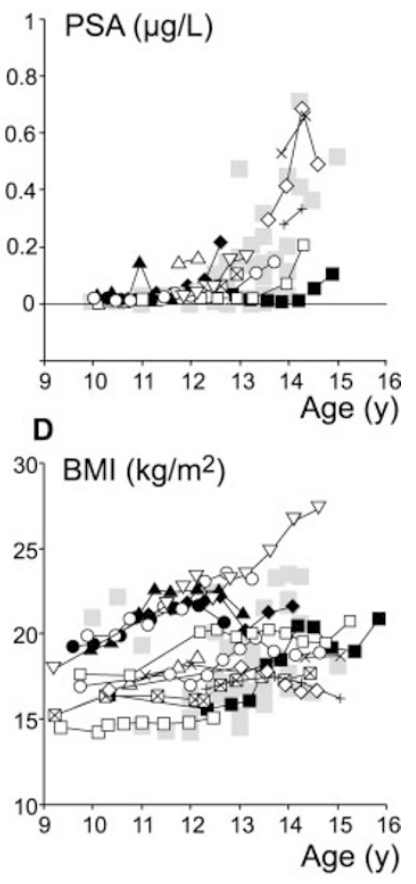

healthy boys

Figure 3. Longitudinal changes in serum SHBG concentrations $(A)$, prostatespecific antigen (PSA) $(B)$, leptin $(C)$, body mass index (BMI) $(D)$, and leptin to BMI ratio $(E)$ during puberty in 14 boys with $\mathrm{KS}$, compared with levels in 25 healthy boys with CDP $(21,22)$. CA are shown for boys with KS, and BA for boys with CDP.

Development of exaggerated $\mathrm{LH}$ and $\mathrm{FSH}$ responses to $\boldsymbol{G n R H}$. To evaluate activity of the pituitary-gonadal axis during puberty in boys with $\mathrm{KS}$, their responses to $\mathrm{GnRH}$ stimulation were studied during follow-up. In the KS boys, pathologically accentuated LH and FSH responses to GnRH stimulation developed during midpuberty, at the age of 13-14 y (Fig. 4, A and $B$, Table 1), with FSH responses becoming exaggerated earlier than did LH responses. In the KS boys, both FSH responses to GnRH stimulation and ratio of inhibin B/FSH (measured before GnRH stimulation) became clearly pathologic when serum inhibin B levels declined (Fig. 4, $C$ and $D$ ).

\section{DISCUSSION}

This study shows that rate of pubertal progression in KS boys, as assessed by Tanner P and G stages, was normal. Our results are in agreement with previous findings $(8,9,13,28)$. In addition, onset of puberty as judged by the appearance of pubic hair and initial testicular enlargement was normal. Testicular volume mainly consists of the seminiferous tubules.

A
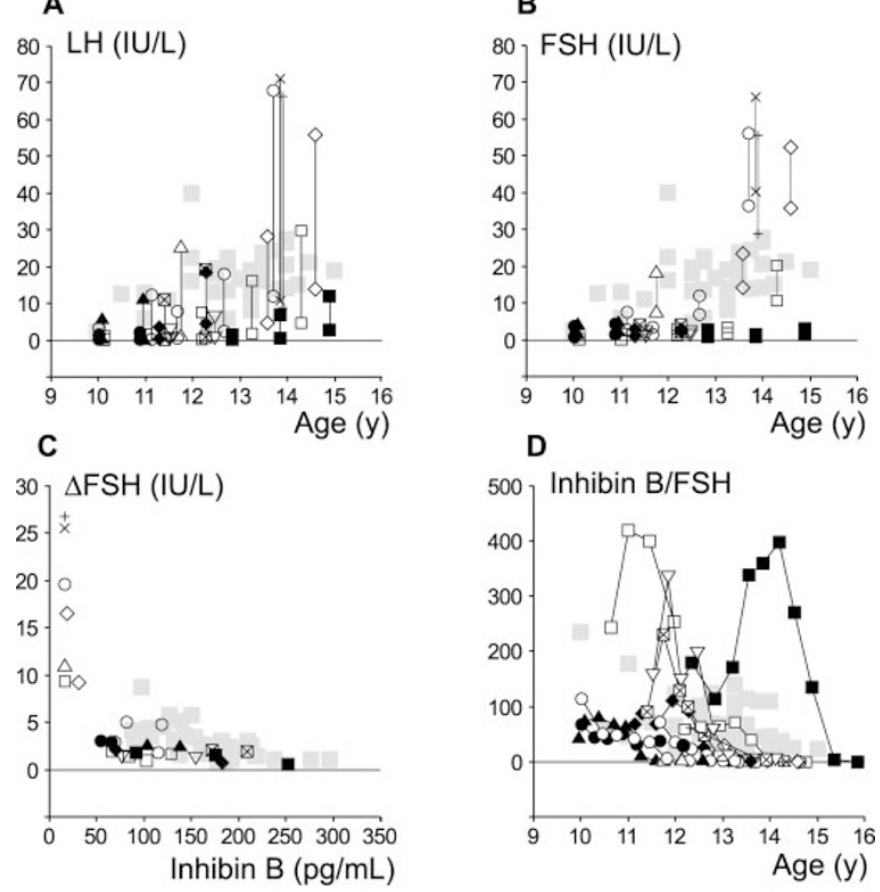

healthy boys

Figure 4. Development of hypergonadotropism in 14 boys with KS during puberty. Serum LH responses $(A)$ and serum FSH responses $(B)$ after GnRH stimulation, showing basal and stimulated maximum in each subject, maximal responses in serum FSH to GnRH stimulation against serum inhibin B concentrations $(C)$, and serum inhibin $\mathrm{B} / \mathrm{FSH}$ ratios $(D)$, compared with maximal responses to $\mathrm{GnRH}$ and serum inhibin $\mathrm{B}$ in 25 healthy boys with CDP $(21,22)$. CA are shown for boys with KS and BA for boys with CDP.

In pubertal KS boys, testicular growth is impaired due to degeneration of the seminiferous tubules, a process that is closely associated to the increase in testosterone secretion (5). Therefore, testicular volumes do not reliably reflect pubertal virilization in KS boys. Furthermore, KS boys have smaller testes already before puberty, $1.0-1.5 \mathrm{~mL}$ (normal, $1.8 \mathrm{~mL}$ ) $(5,7)$. Consequently, to indicate onset of puberty in these KS boys, we accepted a smaller testicular volume $(2.0 \mathrm{~mL})$ than the standard limit of $3.0 \mathrm{~mL}$ that is used to define onset of puberty in healthy boys (29).

In the $47, \mathrm{XXY}$ boys, skeletal maturation fell within the normal range for healthy Finnish boys (27). A similar pattern in skeletal maturation was noticed by Stewart et al. (28). Thus, we found no phenotypic evidence for androgen deficiency in boys with KS during early and midpuberty.

Circulating serum $\mathrm{T}$ levels in the KS boys did not differ from those in the control boys. This is in agreement with the normal progression of puberty, and with data from previous studies $(7-9,28)$. Thus, impaired $T$ secretion is not an evident feature of KS boys during puberty. In fact, to our knowledge, only two studies on KS boys have demonstrated diminished T secretion before puberty $(30,31)$, but these studies comprised infant KS boys, and the results cannot therefore be directly extrapolated to peripubertal and pubertal KS subjects.

However, circulating $\mathrm{T}$ concentrations do not necessarily reflect androgen activity at tissue level. To address this question, we measured serum levels of SHBG, PSA, and leptin, the 
concentrations of which all are, at least to some extent, regulated by androgens. In our KS boys, serum SHBG decreased normally and the levels did not differ from those observed in the controls. During puberty, serum PSA levels are in healthy boys a potential marker of T action (32-35). The normal increase in serum PSA during puberty in our cohort of boys with KS suggests sufficient androgen action in the prostate. Thus, as assessed by serum SHBG and PSA measurements, these KS boys displayed no evidence of diminished androgen action at the cellular level.

A time- and dose-dependent decrease in leptin production occurs in human adipocytes exposed to $\mathrm{T}$ (36). During puberty, serum leptin levels decrease in close correlation with $\mathrm{T}$ levels (37-39). Wabitsch et al. (36) have shown that the leptin/BMI ratio is a good indicator of androgen action. We found in the KS boys higher leptin and higher leptin/BMI ratios than in control boys, suggesting diminished androgen action in adipose tissue. This does not unequivocally reflect deficient androgen action in boys with KS, since serum leptin levels are also regulated by factors other than T. For example, in healthy pubertal girls, leptin and E2 concentrations correlate positively, yet this relationship has not been verified in healthy pubertal boys $(36,38,39)$. Because adolescent KS boys have high serum E2 levels, we cannot exclude the possibility that a threshold effect plays a role, and that in these boys actually a positive correlation exists between E2 and leptin levels. Thus, we cannot exclude an impact of elevated E2 levels on serum leptin levels in KS boys.

No signs of hypergonadotropism were detectable in the KS boys during prepuberty or early puberty. After midpuberty, however, concomitantly with elevations in basal FSH and LH levels, their response to GnRH stimulation became abnormal. These observations are in agreement with earlier findings $(8,9,28)$ and suggest diminished testicular inhibition of gonadotropin secretion. In addition, the boys with KS developed after midpuberty low $\mathrm{T} / \mathrm{LH}$ ratios. This timing is in agreement with gradual appearance of Leydig cell hyperplasia during midpuberty (5). Such changes in activity of the hypothalamicpituitary-testicular axis thus probably represent a state of compensated hypergonadotropic hypogonadism attributed to diminished responsiveness of Leydig cells to LH with advancing puberty.

As our reference group for serum PSA, leptin, FSH, LH, and inhibin B levels, we could only use 25 boys with CDP, who may, however, have altered dynamics in these hormone levels compared with normal boys with normal pubertal progression.

In conclusion, we found that the KS boys had sufficient $\mathrm{T}$ levels to allow normal progression of puberty. At tissue level, adequate androgen action was suggested by normal pubertal changes in serum SHBG and PSA. On the other hand, some of our findings such as an increased incidence of gynecomastia, higher leptin levels, and exaggerated responses to $\mathrm{GnRH}$ stimulation after midpuberty suggest the development of a relative testosterone deficiency. But, overall, no indisputable androgen deficiency appeared in KS boys, and thus they would require no androgen supplementation during early puberty. However, further studies regarding the efficacy of early androgen substitution on the classical symptoms of KS, especially on neurodevelopmental and psychosocial outcome, are strongly needed (15). All the characteristics of the KS phenotype cannot be ascribed to the relative hypogonadism; other factors, such as the excess of X-chromosome genes, probably also have an impact.

\section{REFERENCES}

1. Bojesen A, Juul S, Gravholt CH 2003 Prenatal and postnatal prevalence of Klinefelter syndrome: a national registry study. J Clin Endocrinol Metab 88:622-626

2. Lanfranco F, Kamischke A, Zitzmann M, Nieschlag E 2004 Klinefelter's syndrome. Lancet 364:273-283

3. Ratcliffe S 1999 Long-term outcome in children of sex chromosome abnormalities. Arch Dis Child 80:192-195

4. Klinefelter HF NJr., Reifenstein EC Jr, Albright F 1942 Syndrome characterized by gynecomastia, aspermatogenesis without a-Leydigism and increased excretion of follicle-stimulating hormone. J Clin Endocrin 2:615-624

5. Wikstrom AM, Raivio T, Hadziselimovic F, Wikstrom S, Tuuri T, Dunkel L 2004 Klinefelter syndrome in adolescence: onset of puberty is associated with accelerated germ cell depletion. J Clin Endocrinol Metab 89:2263-2270

6. Laron Z, Hochman IH 1971 Small testes in prepubetal boys with Klinefelter's syndrome. J Clin Endocrinol Metab 32:671-672

7. Robinson A, Bender BG, Borelli JB, Puck MH, Salbenblatt JA, Winter JS 1986 Sex chromosomal aneuploidy: prospective and longitudinal studies. Birth Defects Orig Artic Ser 22:23-71

8. Salbenblatt JA, Bender BG, Puck MH, Robinson A, Faiman C, Winter JS 1985 Pituitary-gonadal function in Klinefelter syndrome before and during puberty. Pediatr Res 19:82-86

9. Topper E, Dickerman Z, Prager-Lewin R, Kaufman H, Maimon Z, Laron Z 1982 Puberty in 24 patients with Klinefelter syndrome. Eur J Pediatr 139:8-12

10. Smyth CM, Bremner WJ 1998 Klinefelter syndrome. Arch Intern Med 158:13091314

11. Myhre SA, Ruvalcaba RH, Johnson HR, Thuline HC, Kelley VC 1970 The effects of testosterone treatment in Klinefelter's syndrome. J Pediatr 76:267-276

12. Nielsen J, Pelsen B, Sorensen K 1988 Follow-up of 30 Klinefelter males treated with testosterone. Clin Genet 33:262-269

13. Sorensen K 1992 Physical and mental development of adolescent males with Klinefelter syndrome. Horm Res 37:55-61

14. Patwardhan AJ, Eliez S, Bender B, Linden MG, Reiss AL 2000 Brain morphology in Klinefelter syndrome: extra $\mathrm{X}$ chromosome and testosterone supplementation. Neurology 54:2218-2223

15. Simpson JL, de la Cruz F, Swerdloff RS, Samango-Sprouse C, Skakkebaek NE, Graham JM Jr, Hassold T, Aylstock M, Meyer-Bahlburg HF, Willard HF, Hall JG, Salameh W, Boone K, Staessen C, Geschwind D, Giedd J, Dobs AS, Rogol A, Brinton B, Paulsen CA 2003 Klinefelter syndrome: expanding the phenotype and identifying new research directions. Genet Med 5:460-468

16. Greulich WW, Pyle SL 1959 Radiographic Atlas of Skeletal Development of the Hand and Wrist, 2nd ed. Stanford University Press, Stanford, CA, pp 97-119

17. Tanner JM 1962 Growth at Adolescence; With a General Consideration of the Effects of Hereditary and Environmental Factors upon Growth and Maturation from Birth to Maturity, 2nd ed. Blackwell, Oxford, UK, pp 22-29

18. Hansen PF, With TK 1952 Clinical measurements of testes in boys and men. Acta Med Scand 266:457-465

19. Ankarberg-Lindgren C, Norjavaara E 2004 Changes of diurnal rhythm and levels of total and free testosterone secretion from pre to late puberty in boys: testis size of 3 $\mathrm{ml}$ is a transition stage to puberty. Eur J Endocrinol 151:747-757

20. Ankarberg Lindgren C 2005 Testosterone and $17 \beta$-oestradiol secretion in children and adolescents: assay development, levels for comparison and clinical applications. Göteborg Pediatric Growth Research Center, Department of Pediatrics. Sahlgrenska Academy at Göteborg University, Göteborg, Sweden, pp 46-52

21. Wickman S, Sipila I, Ankarberg-Lindgren C, Norjavaara E, Dunkel L 2001 A specific aromatase inhibitor and potential increase in adult height in boys with delayed puberty: a randomised controlled trial. Lancet 357:1743-1748

22. Raivio T, Dunkel L, Wickman S, Janne OA 2004 Serum androgen bioactivity in adolescence: a longitudinal study of boys with constitutional delay of puberty. J Clin Endocrinol Metab 89:1188-1192

23. Ankarberg C, Norjavaara E 1999 Diurnal rhythm of testosterone secretion before and throughout puberty in healthy girls: correlation with 17beta-estradiol and dehydroepiandrosterone sulfate. J Clin Endocrinol Metab 84:975-984

24. Norjavaara E, Ankarberg C, Albertsson-Wikland K 1996 Diurnal rhythm of 17 beta-estradiol secretion throughout pubertal development in healthy girls: evaluation by a sensitive radioimmunoassay. J Clin Endocrinol Metab 81:4095-4102

25. Dunkel L, Alfthan H, Stenman UH, Perheentupa J 1990 Gonadal control of pulsatile secretion of luteinizing hormone and follicle-stimulating hormone in prepubertal boys evaluated by ultrasensitive time-resolved immunofluorometric assays. J Clin Endocrinol Metab 70:107-114

26. Matthews JN, Altman DG, Campbell MJ, Royston P 1990 Analysis of serial measurements in medical research. BMJ 300:230-235

27. Ojajärvi P 1982 The adolescent Finnish child, a longitudinal study of the anthropometry, physical development and physiological changes during puberty. $\mathrm{PhD}$ Thesis, University of Helsinki, Helsinki, Finland, pp 1-140 
28. Stewart DA, Bailey JD, Netley CT, Rovet J, Park E 1986 Growth and development from early to midadolescence of children with $\mathrm{X}$ and $\mathrm{Y}$ chromosome aneuploidy: the Toronto Study. Birth Defects Orig Artic Ser 22:119-182

29. Styne DM 2002 The Testes: Disorders of Sexual Differentiation and Puberty in the Male. In: Sperling MA (ed) Pediatric Endocrinology, 2nd ed. Saunders, Philadelphia, pp 598-599

30. Lahlou N, Fennoy I, Carel JC, Roger M 2004 Inhibin B and anti-Mullerian hormone, but not testosterone levels, are normal in infants with nonmosaic Klinefelter syndrome. J Clin Endocrinol Metab 89:1864-1868

31. Ross JL, Samango-Sprouse C, Lahlou N, Kowal K, Elder FF, Zinn A 2005 Early androgen deficiency in infants and young boys with 47,XXY Klinefelter syndrome. Horm Res 64:39-45

32. Vieira JG, Nishida SK, Pereira AB, Arraes RF, Verreschi IT 1994 Serum levels of prostate-specific antigen in normal boys throughout puberty. J Clin Endocrinol Metab 78:1185-1187

33. Randell EW, Diamandis EP, Ellis G 1996 Serum prostate-specific antigen measured in children from birth to age 18 years. Clin Chem 42:420-423

34. Juul A, Muller J, Skakkebaek NE 1997 Prostate specific antigen in boys with precocious puberty before and during gonadal suppression by $\mathrm{GnRH}$ agonist treatment. Eur J Endocrinol 136:401-405
35. Kim MR, Gupta MK, Travers SH, Rogers DG, Van Lente F, Faiman C 1999 Serum prostate specific antigen, sex hormone binding globulin and free androgen index as markers of pubertal development in boys. Clin Endocrinol (Oxf) 50:203210

36. Wabitsch M, Blum WF, Muche R, Braun M, Hube F, Rascher W, Heinze E, Teller W, Hauner H 1997 Contribution of androgens to the gender difference in leptin production in obese children and adolescents. J Clin Invest 100:808-813

37. Garcia-Mayor RV, Andrade MA, Rios M, Lage M, Dieguez C, Casanueva FF 1997 Serum leptin levels in normal children: relationship to age, gender, body mass index, pituitary-gonadal hormones, and pubertal stage. J Clin Endocrinol Metab 82:28492855

38. Blum WF, Englaro P, Hanitsch S, Juul A, Hertel NT, Muller J, Skakkebaek NE, Heiman ML, Birkett M, Attanasio AM, Kiess W, Rascher W 1997 Plasma leptin levels in healthy children and adolescents: dependence on body mass index, body fat mass, gender, pubertal stage, and testosterone. J Clin Endocrinol Metab 82:29042910

39. Ankarberg-Lindgren C, Dahlgren J, Carlsson B, Rosberg S, Carlsson L, Wikland KA, Norjavaara E 2001 Leptin levels show diurnal variation throughout puberty in healthy children, and follow a gender-specific pattern. Eur J Endocrinol $145: 43-51$ 